\title{
The Effect of Feedback on the Application of Based Chemistry Practicum Modules on Local Content-Students' Science Process Skills
}

\author{
Ratih Permana Sari ${ }^{* *}$, Molani Paulina Hasibuan², Sulastri ${ }^{3}$ iD \\ ${ }^{1,2}$ Pendidikan Kimia, Universitas Samudra, Indonesia \\ ${ }^{3}$ Pendidikan Kimia, Universitas Syiah Kuala, indonesia \\ *Corresponding author: ratihps@unsam.ac.id
}

\begin{abstract}
This study aims to analyze the effect of feedback from local content-based practicum modules on students' science process skills. Research subjects for product trials developed in this study were students of class XI using a purposive sampling technique with a sample size of 60 students. The method used in this research is quasi-experimental (quasi-experimental). The research instrument was a feedback rubric on applying a local content-based practicum module, observation sheets, and tests on the results of Science Process Skills (KPS). Data processing and analysis is carried out by comparing the initial and final science process skills scores by looking at the science process skills N-Gain score. Hypothesis testing uses the T-test to apply a local content-based practicum module on science process skills by analyzing the initial and final science process skills scores. The highest percentage result lies in the indicator of planning an experiment or investigation and using experimental tools and materials, namely $90 \%$. There is a difference between a class that implements a local content-based practicum module and is given feedback with a class that uses a regular module for each class. The experimental class had an $\mathrm{N}$-gain value of 0.75 or in the high category, while the control class had an N-gain value of 0.64 or in the moderate category. There are differences in students' Science Process Skills (KPS) using local content-based practicum modules with conventional practicum modules.
\end{abstract}

Keywords: Science Process Skills, Chemical Module, Feedback

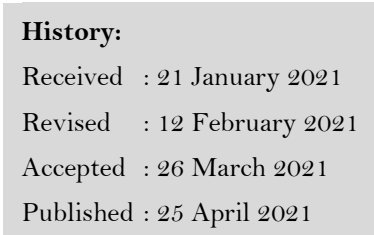

\section{Introduction}

Chemistry is a branch of natural science (IPA) that has a parallel role with other branches of science, such as physics, biology, geology, and astronomy (Indayatmi, 2017; Mintarto, 2007; Murdika, 2018). Therefore, chemistry learning is considered essential to learn. Improving the quality of thinking and learning in schools is influenced by high student motivation, and the quality of learning will influence increased student learning outcomes. Chemistry learning is learning in the form of knowledge transfer and a constructivism process that facilitates students to practice skills, build their own cognitive, and foster positive attitudes. In this learning process, the skills referred to in this learning process are that students are required to experience themselves, seek the truth, or try to find a law or argument, and draw conclusions on the process they are experiencing (Andani \& Yulian, 2018; Kirna, 2012; Pane, 2013). These skills can be found during practicum lessons.

Practical activity is one of the activities that play a significant role in improving the success of the teaching and learning process. Practicum-based learning can be used as an 
alternative to learning that can actively encourage students to learn to reconstruct their conceptual understanding. In science, education laboratory activities (practicum) are an integral part of teaching and learning activities (Amna, n.d.; Hairida, 2018; Nahadi et al., 2017). This shows how important the role of the practicum is to achieve the goals of science education. One of the teaching materials to support the smooth running of the practicum is the practicum module.

Based on observations and interviews with chemistry teachers, information was obtained that the State Senior High School in Langsa City had not implemented practicum learning using practicum modules, especially in utilizing materials derived from nature. Therefore, the application of this practicum module plays an essential role in carrying out the activity process in improving student skills. The process of carrying out activities related to science is usually called Science Process Skills (KPS). Science Process Skills are the ability of students to apply scientific methods in understanding, developing science, and discovering knowledge (Adnyani et al., 2017; Sumarti et al., 2018; Timutiasari et al., 2016).

Science Process Skills are essential for every student to use scientific methods in developing science to acquire new knowledge or develop existing knowledge (Adi \& Widodo, 2018; Sayekti \& Kinasih, 2018; Yusuf \& Wulan, 2015). Process skills can be interpreted as a process approach in teaching natural science based on observations of what a scientist does (Ismail et al., 2016; Mukaromah, 2018; Wiyoko et al., 2019). Students' science process skills can be seen from the selection of appropriate and appropriate practicum modules. Modules are indispensable in practicum activities; apart from being a practical guide, modules can also be designed to direct students to work with scientific steps. Module teaching materials must be arranged systematically and attractively so that students can learn independently. Learning modules are structured teaching materials. Systematically and attractively, that includes material content, methods, and evaluation that can be used independently to achieve the expected competencies (Febriana et al., 2020; Pratiwi et al., 2017; Timutiasari et al., 2016).

Practical materials available in schools have not made learning more meaningful because students have not been able to link the knowledge gained with the phenomena that occur around them because students do not gain experience to relate to them. Therefore, it is necessary to carry out further research in contextual practicum modules, namely by bringing out regional local wisdom. Local wisdom has cultural values and develops in the local scope of the next generation that needs to be understood and by the community absorbed (Khaerunnnisa \& Pamungkas, 2018; Putri et al., 2018; Saidah \& Damariswara, 2019). The application of local wisdom-based learning can be started to support schools in teaching students to act in harmony with the environment. The advantages of developing a chemical practicum module based on local wisdom with the manual for making, using, and providing feedback during the implementation of the practicum can help teachers explain chemical concepts and help students improving their science process skills for relating the concepts obtained to phenomena in life, more sensitive to the surrounding environment, more loving and preserving the local wisdom of their respective regions (Amna, n.d.; Nahadi et al., 2017; Riza et al., 2020).

This research is supported by several relevant studies such as (1) research conducted by Timutiasari et al. (2016), which obtained the results of the research that there was an effect of project-based learning assisted by the KRPL program module to develop environmental care attitudes and students' science process skills; (2) research conducted by Yusuf \& Wulan (2015), who obtained research results that the application of learning models discovery learning using learning shared types of and webbed can improve science process skills; (3) research conducted by Wijanarko et al. (2017), who obtained research results that the PjBL model was effective in improving student learning outcomes and 
process skills. This study aimed to analyze the effect of feedback from the application ofbased practicum modules local content on students' science process skills.

This study aims to analyze the effect of feedback from local content-based practicum modules on students' science process skills. Developing a chemical practicum module based on local wisdom along with the manual for making and using it as well as providing feedback during the implementation of the practicum can help teachers explain chemical concepts and also help students improve their science process skills so that they can relate the concepts obtained to phenomena in life, more sensitive to the surrounding environment, more loving and preserving the local wisdom of their respective regions

\section{Materials and Methods}

This research is quasi-experimental (quasi-experimental). Quasi-experimental research was conducted to test hypotheses; whether there is an effect of action than other actions by controlling variables and the existing conditions (situational). This study used a research non-equivalent control group design (Erina \& Kuswanto, 2015; Fatimah, 2017; Lestari \& Diana, 2018). Research subjects for product trials developed in this study were students of class XI SMA Negeri 1 in Aceh province for the 2019/2020 school year using a purposive sampling technique with a sample size of 60 students.

The method used to obtain data in this study consisted of data on the response to the test results, namely data obtained from field trials. This field trial data is divided into three stages: the validation and reliability testing phase, followed by the application phase. The instruments of this research are questionnaires, observation sheets, and test results of science process skills. Indicators of science process skills assessed in this study can be seen in Table 2.

Table 2. Indicators of Science Process Skills

\begin{tabular}{|c|c|c|}
\hline No & Indicator & Sub Indicator \\
\hline 1 & Observation & Using the sense of sight, gather/use relevant facts \\
\hline 2 & Classify & $\begin{array}{l}\text { Take note of each observation separately look for } \\
\text { differences, similarities. Contrast Feature }\end{array}$ \\
\hline 3 & Interpret & Conclude \\
\hline 4 & Forecasting/Predicting & $\begin{array}{l}\text { Presenting what might have happened in a situation } \\
\text { that had not yet happened. Presenting what might have } \\
\text { happened in a situation that had not yet happened }\end{array}$ \\
\hline & & Describe the experimental data using tables or graphs \\
\hline 5 & Communicating & Prepare and submit reports clearly \\
\hline & & Describe the results of the experiment \\
\hline 6 & Asking question & $\begin{array}{l}\text { Asking questions to ask for explanations / asking } \\
\text { questions with a hypothetical background }\end{array}$ \\
\hline 7 & Propose a hypothesis & Realized that one explanation need to be verified \\
\hline 8 & $\begin{array}{l}\text { Planning an experiment } \\
\text { or investigation }\end{array}$ & $\begin{array}{l}\text { Determine the tools, materials, and sources to be used. } \\
\text { Determine what to organize, observe and record. } \\
\text { Determine what will be carried out in the form of work } \\
\text { steps }\end{array}$ \\
\hline 0 & Using tools, materials & Using tools, materials, or resources \\
\hline & or source & Find out why using a tool, material, or source \\
\hline 10 & Apply the concept & Using learned concepts in new situations \\
\hline 11 & $\begin{array}{l}\text { Doing an experiment } \\
\text { or investigation }\end{array}$ & $\begin{array}{l}\text { Using concepts to conduct experiments } \\
\text { investigations }\end{array}$ \\
\hline
\end{tabular}


The data listed on the practicum compliance observation sheet were analyzed by calculating the percentage. Furthermore, the data on science process skills using a rubric determine the highest score of four and the lowest one-processing and data analysis of science process skills done by comparing the initial and final scores. Finally, to see the differences in science process skills, students using local content-based practicum modules with conventional practicum modules were analyzed using the T-test.

\section{Results and Discussion Results}

Recapitulating data was based on observations of various science process skills for classes using content-based local practicum modules and feedback during practicum implementation and classes that do not use content locale-based practicum modules. Their percentages are shown in Table 3.

Table 3. Average Observation Results of Science Process Skills

\begin{tabular}{|c|c|c|c|}
\hline \multirow{2}{*}{ No } & \multirow{2}{*}{ Skills Indicator Process Science } & \multicolumn{2}{|c|}{ Class } \\
\hline & & Control & Experiment \\
\hline 1 & Observe & $66 \%$ & $87 \%$ \\
\hline 2 & Group & $52 \%$ & $75 \%$ \\
\hline 3 & Interpret & $70 \%$ & $89 \%$ \\
\hline 4 & Foretells & $70 \%$ & $85 \%$ \\
\hline 5 & Communicate & $45 \%$ & $75 \%$ \\
\hline 6 & Asking Question & $62 \%$ & $80 \%$ \\
\hline 7 & Put forward a hypothesis & $53 \%$ & $80 \%$ \\
\hline 8 & Planning experiments or investigation & $77 \%$ & $90 \%$ \\
\hline 9 & Using tools, materials or sources & $67 \%$ & $90 \%$ \\
\hline 10 & Apply the concept & $67 \%$ & $85 \%$ \\
\hline 11 & $\begin{array}{l}\text { Perform experimental investigation using } \\
\text { tools }\end{array}$ & $73 \%$ & $85 \%$ \\
\hline & Average & $70,2 \%$ & $84 \%$ \\
\hline
\end{tabular}

The following diagram of the results of the recapitulation of observational data on the implementation of the chemical practicum on acid-base and corrosion indicator materials can be seen in Figure 1.

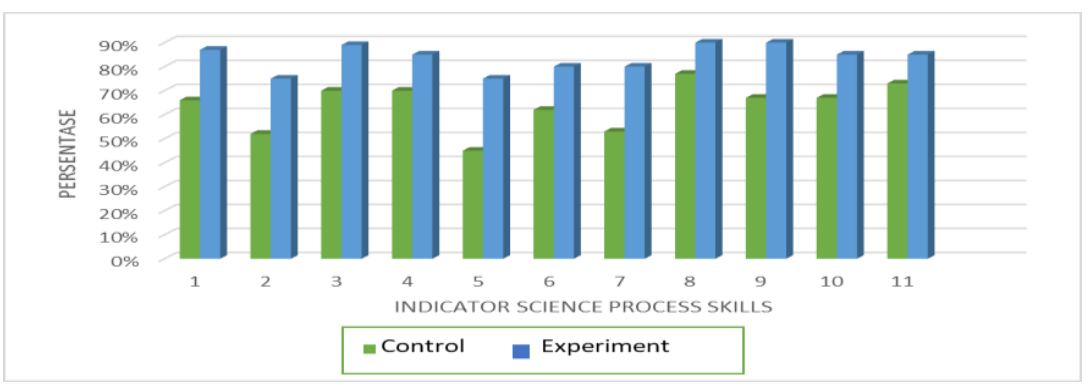

Figure 1. Diagram of Mastery Level of Science Process Skills

The data obtained from the results of this observation shows a difference in the average percentage of all indicators of students' science process skills, especially in the communication indicators of $45 \%$ in the control class and $75 \%$ in the experimental class. 
After being given feedback during the practicum, the students understand better what symptoms cause a chemical process to occur. Therefore, when explaining again, students who are given feedback appear to be easier to communicate when explaining the reaction process. The highest percentage result lies in the indicator of planning an experiment or investigation and using experimental tools and materials, namely $90 \%$. Thus, from the results of science process skills, each indicator shows that the class uses the local content-based practicum module is given feedback during the implementation of the practicum is more skilled in explaining the scientific process that occurs.

The results of data analysis on science process skills after implementing the local content-based practicum module gave feedback during the practicum implementation showed a significant difference between the control group and the experimental group. Furthermore, the local content-based practicum module and feedback during the practicum implementation applied in the experimental group influenced students' science process skills. A practical module based on local content and given feedback during the practicum implementation is the implementation of experimental methods carried out by students in the laboratory. Experiments significantly improve students' science process skills because, with experiments, students work alone, prepare their own tools and materials, and carry out their experiments given by the teacher. Following research conducted by Aslan (2017), Diani (2015), Lestari \& Diana (2018), chemical experiments provide experience and fun for students in learning chemistry.

Experiments associated with everyday life and associated with natural materials also provide experiences for students in conducting experiments, and of course, students are more active in learning. Following what was stated by Chrisyarani \& Yasa (2018), Jatmiko (2015), Riza et al. (2020) that practicum modules based on local wisdom or local content can provide experience, are familiar with experiments, and increase theoretical knowledge. This was shown by the experimental group, which showed higher science process skills than the control group. In the experimental group, the application of a-based practicum module local content made students more active on their own compared to the control group, who only paid attention to demonstrations by the teacher, so it was clear that the experimental group was higher in terms of students' science process skills. The results of this study are also in line with Pamungkas et al. (2017), Riza et al. (2020), Utari et al. (2016) that integrating local wisdom in contextual learning will undoubtedly help to practice understanding the concept of acid-base. Concept understanding can be interpreted as the ability of students to understand the meaning scientifically, both in theory and its application in everyday life. The N-data Gain of students' science process skills was obtained from normalized gain (N-Gain). Based on the data analysis in each class, it was obtained that the $\mathrm{N}$-Gain science process skills of the control class students were 0.60 , which was included in the medium category and the $\mathrm{N}$ Gain experimental class was 0.75 , which was included in the high category. The value of science process skills before and after implementing a-based practicum module local content can be seen in Table 4.

Table 4. The value of Science Process Skills before and after the implementation of local content-based practicum modules.

\begin{tabular}{llcccl}
\hline No. & Name & $\begin{array}{c}\text { Initial KPS } \\
\text { Value }\end{array}$ & $\begin{array}{c}\text { Final KPS } \\
\text { Value }\end{array}$ & $N$-gain & Category \\
\hline 1. & Class Control & 36 & 77 & 0,64 & Moderate \\
2. & Class Experiment & 52 & 85 & 0,75 & High \\
\hline Averange & 44 & 77 & 0,66 & Moderate \\
\hline
\end{tabular}


Recapitulation of data was based on observations of various science process skills for classes using content-based local practicum modules and feedback during practicum implementation and classes that do not use content locale-based practicum modules. Their percentages are shown in Table 5.

Table 5. Recapitulation of local content-based practicum modules T-Test.

\begin{tabular}{lllccrl}
\hline Group & Average & Varians & t-hit & $\mathrm{P}(\alpha)$ & Interpretation & Conclusion \\
\hline Class & 6,50 & 66,6 & 0,001 & 0,05 & thit $<\mathrm{P}$ & $\begin{array}{l}\text { There is a } \\
\text { significant } \\
\text { Control }\end{array}$ \\
$\begin{array}{l}\text { Class } \\
\text { Experiment }\end{array}$ & 8,75 & 40,5 & & & & difference \\
\hline
\end{tabular}

Based on Table 5, the significance test results show the value of $t=0.00<0.05$, so it can be concluded that different Science process skills (KPS) students use-based local content practicum modules with conventional practicum modules. In addition to differences in science process skills, students' motivation to learn chemistry also increases with practical modules based on local content and given feedback.

\section{Discussion}

The learning motivation of the control and experimental groups before implementing the-based practicum module local content and being given feedback showed different motivations for the two groups. The experimental group has higher learning motivation than the control group. Many things can cause differences in the motivation of the two groups, including when filling out the questionnaire response, where students did not read the statements, so they only checked them at will, the class atmosphere when filling out the motivation questionnaire, when filling out the questionnaire and so on. The absence of reading the questionnaire statement significantly affects the score results because the statements provided in the questionnaire are not only positive statements but also negative statements (Sukmawa et al., 2019; Sumarti et al., 2018; Widayanti et al., 2018). The scores for negative statements are different from the scores for positive statements. This mainly occurs because applying the learning model using practicum modules accommodates students to maximize skills in carrying out practicum activities. This situation does not occur when the learning process in class is only in lectures and questions and answers.

The students' participation in practicum activities using modules can encourage them to ask questions, formulate hypotheses, conduct experiments, use tools to collect data, analyze data, and conclude and argue. These can develop students 'scientific work skills and make students learn actively in finding concepts so that they are suitable to be used to improve students' scientific work skills (Lestari \& Diana, 2018; Nahadi et al., 2017; Rizkiana et al., 2016). Based on the study results, it can be revealed that students who learn without using modules students will only depend on the knowledge provided by the teacher without being able to learn it again. Thus, improving students' science process skills towards learning and finding their concepts in the learning process involves practicing activities whose materials are sourced from local wisdom-based practicum modules.

Science Process Skills are essential for every student to use scientific methods in developing science to acquire new knowledge or develop existing knowledge (Adi \& Widodo, 2018; Sayekti \& Kinasih, 2018; Yusuf \& Wulan, 2015). Process skills can be interpreted as a process approach in teaching natural science based on observations of what a scientist does (Ismail et al., 2016; Mukaromah, 2018; Wiyoko et al., 2019). Science process skills can be seen from the use of appropriate and appropriate practicum modules. 
Modules are indispensable in practicum activities; apart from being a practical guide, modules can also be designed to direct students to work with scientific steps. Module teaching materials must be arranged systematically and attractively so that students can learn independently, as expressed by Febriana et al. (2020; Pratiwi et al. (2017); Timutiasari et al. (2016) that learning modules are structured teaching materials, systematically and attractively that includes material content, methods, and evaluation that can be used independently to achieve the expected competencies. The advantages of developing a chemical practicum module based on local wisdom with the manual for making and using it as well as providing feedback during the implementation of the practicum can help teachers explain chemical concepts and also help students improve their science process skills so that they can relate the concepts obtained to phenomena in life, more sensitive to the surrounding environment, more loving and preserving the local wisdom of their respective regions (Amna, n.d.; Nahadi et al., 2017; Riza et al., 2020).

This research is supported by several relevant studies such as (1) research conducted by Timutiasari et al. (2016), which obtained the results of the research that there was an effect of project-based learning assisted by the KRPL program module to develop environmental care attitudes and students' science process skills. ; (2) research conducted by Yusuf \& Wulan (2015), who obtained research results that the application of learning models discovery learning using learning shared types of and webbed can improve science process skills; (3) research conducted by Wijanarko et al. (2017), who obtained research results that the PjBL model was effective in improving student learning outcomes and process skills. This study aimed to analyze the effect of feedback from the application ofbased practicum modules local content on students' science process skills. This research implies that besides increasing students 'science process skills, it can also improve students' conceptual understanding of phenomena in life, be more sensitive to the surrounding environment, love the surrounding environment more, and preserve the local wisdom of their respective regions.

\section{Conclusion}

Based on the results of the data, the highest percentage results lie in the indicators of planning experiments or investigations and using experimental tools and materials so that it can be concluded that there are differences in Science Process Skills (KPS) students usingbased local content practicum modules with conventional practicum modules. This research implies that besides increasing students 'science process skills, it can also improve students' conceptual understanding of phenomena in life, be more sensitive to the surrounding environment, love the surrounding environment more, and preserve the local wisdom of their respective regions.

\section{References}

Adi, Y. K., \& Widodo, A. (2018). Pemahaman Hakikat Sains Pada Guru Dan Siswa Sekolah Dasar. Edukasi Journal, 10(1), 55-72. https://doi.org/10.31603/edukasi.v10i1.1831.

Adnyani, A. M., Ardana, I. K., \& Putra, I. K. A. (2017). Pengaruh Pendekatan Saintifik Berbantuan Model Sains Teknologi Masyarakat Terhadap Kompetensi Pengetahuan Ipa Siswa Kelas V. Journal of Education Technology, 1(2), 94. https://doi.org/10.23887/jet.v1i2.11746.

Amna, E. (n.d.). Laboratorium sebagai sarana pembelajaran kimia dalam Meningkatkan pengetahuan dan ketrampilan kerja ilmiah. Lantanida Journal, 2(2). https://doi.org/10.22373/lj.v2i2.1409.

Andani, D. T., \& Yulian, M. (2018). Pengembangan Bahan Ajar Electronic Book 
Menggunakan Software Kvisoft Flipbook Pada Materi Hukum Dasar Kimia di SMA Negeri 1 Panton Reu Aceh Barat. Jurnal IPA \& Pembelajaran IPA, 2(1), 1-6. https://doi.org/10.24815/jipi.v2i1.10730.

Aslan, S. (2017). The Effect of Learning by Teaching on Pre-Service Science Teachers' Attitudes towards Chemistry. Journal of Turkish Science Education, 14(3), 1-15. https://doi.org/10.12973/tused.10201a.

Chrisyarani, D. D., \& Yasa, A. D. (2018). Validasi modul pembelajaran: Materi dan desain tematik berbasis PPK. Premiere Educandum, 8(2), 206-212. https://doi.org/10.25273/pe.v8i2.3207.

Diani, R. (2015). Pengembangan Perangkat Pembelajaran Fisika Berbasis Pendidikan Karakter dengan Model Problem Based Instruction. Jurnal Ilmiah Pendidikan Fisika Al-Biruni, 4(2), 241-253. https://doi.org/10.24042/jpifalbiruni.v4i2.96.

Erina, R., \& Kuswanto, H. (2015). Pengaruh Model Pembelajaran Instad Terhadap Keterampilan Proses Sains dan Hasil Belajar Kognitif Fisika di SMA. Jurnal Inovasi Pendidikan IPA, 1(2), 202-211. https://doi.org/10.21831/jipi.v1i2.7507.

Fatimah, S. (2017). Analisis Pemahaman Konsep IPA Berdasarkan Motivasi Belajar, Keterampilan Proses Sains, Kemampuan Multirepresentasi, Jenis Kelamin, Dan Latar Belakang Sekolah Mahasiswa Calon Guru SD. Jurnal Inovasi Pendidikan Dan Pembelajaran Sekolah Dasar, 1(1), 57-70. https://doi.org/10.24036/jippsd.v1i1.7934.

Febriana, R., Yusri, R., \& Delyana, H. (2020). Modul Geometri Ruang Berbasis Problem Based Learning Terhadap Kreativitas Pemecahan Masalah. Aksioma: Jurnal Program Studi Pendidikan Matematika, 9(1), 93. https://doi.org/10.24127/ajpm.v9i1.2591.

Hairida, H. (2018). Penilaian Sikap Siswa Dalam Pembelajaran Kimia Melalui Teknik Self Assessment Dan Peer Assessment. Jurnal Pendidikan Matematika Dan IPA, 9(2), 3748. https://doi.org/10.26418/jpmipa.v9i2.25832.

Indayatmi. (2017). Peningkatan Hasil Belajar Kimia Melalui Model Chemisong Pada Peserta Didik Kimia Analisis. Edusains, 9(1), 42-52. https://doi.org/10.15408/es.v9i1.2878.

Ismail, I., Permanasari, A., \& Setiawan, W. (2016). Efektivitas virtual lab berbasis STEM dalam meningkatkan literasi sains siswa dengan perbedaan gender. Jurnal Inovasi Pendidikan IPA, 2(2), 190-201. https://doi.org/10.21831/jipi.v2i2.8570.

Jatmiko, J. (2015). Eksperimen Model Pembelajaran Think-Pair-Share Dengan Modul(TpsM) Terhadap Prestasi Belajar Matematika Ditinjau Dari Minat Belajar. JIPM (Jurnal Ilmiah Pendidikan Matematika), 3(2), 417-426. https://doi.org/10.25273/jipm.v3i2.511.

Khaerunnnisa, E., \& Pamungkas, A. S. (2018). Pengembangan Instrumen Kecakapan Matematis Dalam Konteks Kearifan Lokal Budaya Banten Pada Materi Bangun Ruang Sisi Datar. Kreano: Jurnal Matematika Kreatif-Inovatif, 9(1). https://doi.org/10.15294/kreano.v9i1.11210.

Kirna, I. (2012). Pemahaman Konseptual Pebelajar Kimia Pemula Dalam Pembelajaran Berbantuan Multimedia Interaktif. Jurnal Ilmu Pendidikan, 18(1), 88-97. https://doi.org/10.17977/jip.v18i1.3387.

Lestari, M. Y., \& Diana, N. (2018). Keterampilan Proses Sains (KPS) Pada Pelaksanaan Praktikum Fisika Dasar I. Indonesian Journal of Science and Mathematics Education, 1(1), 49-54. https://doi.org/10.24042/ijsme.v1i1.2474. 
Mintarto, E. (2007). Meningkatkan Hasil Belajar Kimia Siswa Berpikir Konkret Melalui Latihan Mengorganisasikan Konsep. Jurnal Ilmu Pendidikan, 14(2), 122-126. https://doi.org/10.17977/jip.v14i2.30.

Mukaromah, S. M. (2018). Pengembangan Modul IPA Braille Berbasis Integrasi Islam dan Sains. INKLUSI: Journal of Disability Studies, 5(2), 195-216. https://doi.org/10.14421/ijds.050203.

Murdika. (2018). Penerapan Model Pembelajaran Kooperatif Tipe TGT Untuk Meningkatkan Motivasi dan Aktivitas Belajar Peserta Didik Kelas XMIA-3 SMAN 1 Tanete Rilau (Studi pada Materi Pokok Ikatan Kimia dan Bentuk Geometri). Chemica: Jurnal Ilmiah Kimia Dan Pendidikan Kimia, 19(1), 75. https://doi.org/10.35580/chemica.v19i1.6647.

Nahadi, N., Firman, H., \& Khilda, K. (2017). Pengembangan Instrumen Penilaian Diri Dan Penilaian Teman-Sejawat Untuk Menilai Kinerja Siswa Smk Pada Praktikum Kimia. Jurnal Penelitian Pendidikan Kimia: Kajian Hasil Penelitian Pendidikan Kimia, 4(2). https://doi.org/10.36706/jppk.v4i2.8410.

Pamungkas, A., Subali, B., \& Lunuwih, S. (2017). Implementasi Model Pembelajaran IPA Berbasis Kearifan Lokal untuk Meningkatkan Kreativitas dan Hasil Belajar Siswa. Jurnal Inovasi Pendidikan IPA, 3(2), 118-127. https://doi.org/10.21831/jipi.v3i2.14562.

Pane, E. R. (2013). Pembelajaran Inovatif Kimia Dasar Yang Menyenangkan. Ta'dib, 18(2), 162-168. https://doi.org/10.19109/tjie.v18i02.44.

Pratiwi, P. H., Hidayah, N., \& Martiana, A. (2017). Pengembangan Modul Mata Kuliah Penilaian Pembelajaran Sosiologi Berorientasi Hots. Cakrawala Pendidikan, 36(2), 201-209. https://doi.org/10.21831/cp.v36i2.13123.

Putri, I. H. N., Sholihah, U., Handayani, E. M., \& Sumarmi, S. (2018). Pengembangan Suplemen Bahan Ajar Digital Pada Mata Pelajaran Geografi Dengan Topik Bahasan Sumber Daya Laut Berbasis Kearifan Lokal. Jurnal Pendidikan Geografi, 23(2), 7884. https://doi.org/10.17977/um017v23i22018p078.

Riza, M., Firmansyah, R. ., Zammi, M., \& Djuniadi, D. (2020). Pengembangan modul kimia berbasis kearifan lokal Kota Semarang pada materi larutan asam dan basa. JIPVA (Jurnal Pendidikan IPA Veteran), 4(1), 25-38. https://doi.org/10.31331/jipva.v4i1.1025.

Rizkiana, F., Dasna, I. W., \& Marfu'ah, S. (2016). Pengaruh Praktikum Dan Demonstrasi Dalam Pembelajaran Inkuiri Terbimbing Terhadap Motivasi Belajar Siswa Pada Materi Asam Basa Ditinjau Dari Kemampuan Awal. Jurnal Pendidikan: Teori, Penelitian, Dan Pengembangan, 1(3), 354-362. https://doi.org/10.17977/jp.v1i3.6161.

Saidah, K., \& Damariswara, R. (2019). Pengembangan Bahan Ajar Materi Dongeng Berbasis Kearifan Lokal Jawa Timur Bagi Siswa Kelas III SD. Premiere Educandum : Jurnal Pendidikan Dasar Dan Pembelajaran, 9(1), 73-81. https://doi.org/10.25273/pe.v9i1.4320.

Sayekti, I. C., \& Kinasih, A. M. (2018). Kemampuan Guru Menerapkan Keterampilan Proses Sains Dalam Pembelajaran Ipa Pada Siswa Kelas Iv B Sdm 14 Surakarta. Profesi Pendidikan Dasar, 1(1), 93. https://doi.org/10.23917/ppd.v1i1.4464.

Sukmawa, O., Rosidin, U., \& Sesunan, F. (2019). engembangan Instrumen Asesmen Kinerja 
(Performance Assessment) Praktikum Pada Mata Pelajaran Fisika Di SMA. Jurnal Pendidikan Fisika, 7(1), 116-129. https://doi.org/10.24127/jpf.v7i1.1397.

Sumarti, S. S., Nuswowati, M., \& Kurniawati, E. (2018). Meningkatkan Keterampilan Proses Sains Melalui Pembelajaran Koloid Dengan Lembar Kerja Praktikum Berorientasi Chemo-Entrepreneurship. Phenomenon: Jurnal Pendidikan MIPA, 8(2), 175-184. https://doi.org/10.21580/phen.2018.8.2.2499.

Timutiasari, B., Al-Muhdhar, M. H. I., \& Suhadi. (2016). Pembelajaran berbasis Projek Berbantuan Modul Program KRPL untuk Mengembangkan Sikap Peduli Lingkungan dan Keterampilan Proses Sains Siswa SD Islam Moh. Hatta Malang. Jurnal Pendidikan: Teori, Penelitian, Dan Pengembangan, 1(6), 1185-1190. https://doi.org/10.17977/jp.v1i6.6472.

Utari, U., Degeng, N. D., \& Akbar, S. (2016). Pembelajaran Tematik Berbasis Kearifan Lokal Di Sekolah Dasar Dalam Menghadapi Masyarakat Ekonomi Asean (MEA). Jurnal Teori Dan Praksis Pembelajaran IPS, 1(1), 39-44. https://doi.org/10.17977/um022v1i12016p039.

Widayanti, W., Yuberti, Y., Irwandani, I., \& Hamid, A. (2018). Pengembangan Lembar Kerja Praktikum Percobaan Melde Berbasis Project Based Learning. Jurnal Pendidikan Sains Indonesia, 6(1), 24-31. https://doi.org/10.24815/jpsi.v6i1.10908.

Wijanarko, A. G., Supardi, K. I., \& Marwoto, P. (2017). Keefektifan Model Project Based Learning Terbimbing untuk Meningkatkan Keterampilan Proses Sains dan Hasil Belajar IPA. Journal of Primary Education, 6(2), 120-125. https://doi.org/10.15294/jpe.v6i2.17561.

Wiyoko, T., Megawati, M., Aprizan, A., \& Avana, N. (2019). Peningkatan Kompetensi Siswa Melalui Pembinaan Olimpiade Sains (OSN). Warta LPM, 22(2), 67-75. https://doi.org/10.23917/warta.v22i2.8619.

Yusuf, M., \& Wulan, A. R. (2015). Penerapan Model Pembelajaran Discovery Learning Menggunakan Pembelajaran Tipe Shared dan Webbed untuk Meningkatkan Keterampilan Proses Sains. Jurnal Penelitian \& Pengembangan Pendidikan Fisika, 1(2), 19-26. https://doi.org/10.21009/1.01204. 